\title{
Production of Protease and Amylase from Bacillus subtilis and Aspergillus niger Using Parkia biglobossa (Africa Locust Beans) as Substrate in Solid State Fermentation
}

\author{
Oyeleke S. B.", Oyewole O. A. , Egwim, E. C. \\ Department of Biochemistry, Federal University of Technology, Pmb 65, Minna, Niger State, Nigeria
}

\begin{abstract}
Bacillus subtilis and Aspergillus niger were utilized for the production of amylase and protease enzymes in this study. Parkia biglobossa (Africa Locust Beans) shell was used as substrate by both organisms for the production of amylase and protease enzyme. The optimum temperature for the activity of amylase and protease enzymes produced by Bacillus subtilis was $50^{\circ} \mathrm{C}$, while $30^{\circ} \mathrm{C}$ and $40^{\circ} \mathrm{C}$ was recorded for amylase and protease enzyme produced by Aspergillus niger with an activity of $1.1 \mathrm{mg} / \mathrm{ml} / \mathrm{sec}, 0.8 \mathrm{mg} / \mathrm{ml} / \mathrm{sec}$ for amylase and protease enzyme by Bacillus subtilis and $0.87 \mathrm{mg} / \mathrm{ml} / \mathrm{sec}, 0.77$ $\mathrm{mg} / \mathrm{ml} / \mathrm{sec}$ for amylase and protease produced by Aspergillus niger respectively. Optimum $\mathrm{pH}$ was attained at $\mathrm{pH} 9$ for amylase and protease enzyme produced by Bacillus subtilis with an activity of $1.2 \mathrm{mg} / \mathrm{ml} / \mathrm{sec}$ and $0.83 \mathrm{mg} / \mathrm{ml} / \mathrm{sec}$ respectively. The optimum $\mathrm{pH}$ for the activity of Aspergillus niger was recorded at $\mathrm{pH} 5$ and $\mathrm{pH} 6$ for amylase and protease with an activity of $0.87 \mathrm{mg} / \mathrm{ml} / \mathrm{sec}$ and $0.74 \mathrm{mg} / \mathrm{ml} / \mathrm{sec}$ respectively. The result showed that both organisms utilized Parkia biglobossa to produce extracellular amylase and protease, but the activity of amylase enzyme produced by both organisms was greater than the activity of protease enzyme and enzymes produced by Bacillus subtilis showed superior activity which can be useful industrially.
\end{abstract}

Keywords Bacillus subtilis, Aspergillus niger, Amylase, Protease Enzymes, Parkia biglobossa

\section{Introduction}

Enzymes are substances present in the cells of living organisms in minute amounts and are capable of speeding up chemical reactions (associated with life processes), without themselves being altered after the reaction. They accelerate the velocity of the reaction without necessarily initiating it (Oyeleke and Oduwole, 2009).

Microbial enzymes are preferred to those from both plant and animal sources because they are cheaper to produce, and their enzyme contents are more predictable, controllable and reliable (Burhan et al., 2003). These naturally occurring enzymes are quite often not readily available in sufficient quantities for food applications or industrial use. However, by isolating microbial strains that produce the desired enzyme and optimizing the conditions for growth, commercial quantities can be obtained. This technique, well known for more than 3,000 years, is called fermentation. Some of the typical applications include enzyme use in the production of sweeteners, chocolate syrups, bakery products, alcoholic beverages, precooked cereals, infant foods, fish meal, cheese

* Corresponding author:

droyeleke@yahoo.com (Oyeleke S. B.)

Published online at http://journal.sapub.org/als

Copyright (C) 2011 Scientific \& Academic Publishing. All Rights Reserved and dairy products, egg products, fruit juice, soft drinks, vegetable oil and puree, candy, spice and flavour extracts, and liquid coffee, as well as for dough conditioning, chill proofing of beer, flavour development, and meat tenderizing. Enzymes also play a significant role in non-food applications. Industrial enzymes are used in laundry and dishwashing detergents, stonewashing jeans, pulp and paper manufacture, leather dehairing and tanning, de-sizing of textiles, deinking of paper, and degreasing of hides (Enzyme Technical Association, 2001).

The West African locust bean (dawadawa) belongs to the family leguminosa. The English common name is baobab, probably derived from the Arabic bu hibab, which means "fruit with several seeds" (Kurebgaseka, 2005). Readily available agricultural waste such as the shell of Parkia biglobossa which presently constitutes part of the menace to solid waste management may be used as substrate for growth by microorganism in solid state fermentation.

Agro-industrial residues are generally considered the best substrates for the solid state fermentation processes, and use of solid state fermentation for the production of enzymes is no exception to that. A number of such substrates have been employed for the cultivation of microorganisms to produce host of enzymes. Some of the substrates that have been used included sugar cane bagasse, wheat bran, rice bran, maize bran, gram bran, wheat straw, rice straw, rice husk, soyhull, 
sago hampas, grapevine trimmings dust, saw dust, corncobs, coconut coir pith, banana waste, tea waste, cassava waste, palm oil mill waste, aspen pulp, sugar beet pulp, sweet sorghum pulp, apple pomace, peanut meal, rapeseed cake, coconut oil cake, mustard oil cake, cassava flour, wheat flour, corn flour, steamed rice, steam pre-treated willow, starch, etc (Mitra et al., 1994).

The aim of this research work is to produce enzymes from Aspergillus niger and Bacillus subtilis using Parkia biglobossa (African locust beans) shell powder as substrate in solid state fermentation.

\section{Material and Method}

\section{Sample Collection}

Dried fruits of Parkia biglobossa were collected from the crown of standing tree by using a hook to cut the hanging fruits. The tree was located behind the lecture theatre at the Federal University of Technology Minna, Nigeria. The seeds were then removed from the shell and discarded. The shell was further dried in the sun for some days. After drying, it was pounded using a portable mortal. It was then sieved and the filtrate was collected and stored for further use.

Five gram of soil sample was collected at the front of the Microbiology laboratory of the Federal University of Technology Minna. It was then taken to the laboratory for microbial analysis.

\section{Media Preparation}

The nutrient agar, Sabouraud Dextrose agar and Starch agar medium used for this work were prepared according to the manufacturer's instructions.

\section{Screening for Amylolytic Activity of $A$. niger}

The amylolitic activity of $A$. niger was determined using the starch agar plate method as described by Bertrand et al. (2004). This was done by inoculating the identified organism into Sabourad Dextrose Agar medium which was supplemented with $1 \mathrm{~g}$ of starch. The agar plates were then incubated at $30^{\circ} \mathrm{C}$ for 5 days. After the incubation period, Lugol's iodine solution was added to the culture plate to identify the zones around the cultures. The diameter formed after the addition of iodine solution was measured to represent the amylolytic activity.

\section{Screening for Amylolytic Activity of B. subtilis}

The amylolitic activity of the test isolates was determined by using the starch agar plate method, by inoculating the identified Bacillus species into Nutrient Agar medium which was supplemented with $1 \mathrm{~g}$ of starch. The agar plates were then incubated at $37^{\circ} \mathrm{C}$ for $24 \mathrm{hrs}$. After the incubation period, Lugol's iodine solution was added to the culture plate to identify the zones around the cultures. The diameter formed after the addition of iodine solution was measured to represent the amylolytic activity.

\section{Preparation of Medium Used for Amylase Production by} B. subtilis
The medium was prepared by weighing the following medium composition in grams per litre; Bacteriological peptone- $6 \mathrm{~g}, \mathrm{MgSO}_{4} .7 \mathrm{H}_{2} \mathrm{O}-0.5 \mathrm{~g}, \mathrm{KCL}-0.5 \mathrm{~g}$, substrate- $1.0 \mathrm{~g}$. The above medium composition were dissolved in $1000 \mathrm{ml}$ of distilled water after which $100 \mathrm{ml}$ of the medium was measured into a conical flask ( $250 \mathrm{ml}$ capacity each) heated on hot plate to homogenize and then sterilized in an autoclave at $121^{\circ} \mathrm{C}$ for 15 minutes after which they were removed and allowed to cool before the organism was inoculated.

\section{Preparation of the Medium Used for Amylase Product- ion by $A$. niger}

The medium was prepared by weighing the following medium composition in grams per litre; $\mathrm{KH}_{2} \mathrm{PO}_{4}-1.4 \mathrm{~g}$, $\mathrm{NH}_{4} \mathrm{NO}_{3}-10 \mathrm{~g}, \quad \mathrm{KCL}-0.5 \mathrm{~g}, \quad \mathrm{M}_{\mathrm{g}} \mathrm{SO}_{4} .7 \mathrm{H}_{2} \mathrm{O}-0.1 \mathrm{~g}$, $\mathrm{FeSO}_{4} .7 \mathrm{H}_{2} 0-0.01 \mathrm{~g}$, Substrate-20g. The above medium composition were dissolved in $1000 \mathrm{ml}$ of distilled water after which $100 \mathrm{ml}$ of the medium was measured into conical flask $(250 \mathrm{ml}$ capacity each) heated on hot plate to homogenize and then sterilized in an autoclave at $121^{\circ} \mathrm{C}$ for $15 \mathrm{~min}-$ utes after which they were removed and allowed to cool before the organism was inoculated.

\section{Preparation of Medium used for Protease Production by B. subtilis}

The media used for optimized production of protease enzyme consisted of substrate $1 \%(\mathrm{w} / \mathrm{v})$, casein $0.5 \%$, yeast extract $0.55, \mathrm{KH}_{2} \mathrm{PO}_{4} \quad 0.2 \%, \mathrm{Na}_{2} \mathrm{CO}_{3} 1 \%, \mathrm{MgSO}_{4} .7 \mathrm{H}_{2} \mathrm{O}$ $0.2 \%$, substrate and $\mathrm{pH} 8.0$. The above medium composition were dissolved in $1000 \mathrm{ml}$ of distilled water after which $100 \mathrm{ml}$ of the medium was measured into a conical flask ( $250 \mathrm{ml}$ capacity each) heated on hot plate to homogenize and then sterilized in an autoclave at $121^{\circ} \mathrm{C}$ for 15 minutes after which they were removed and allowed to cool before inoculating.

\section{Preparation of Medium used for Protease Production by A. niger}

The medium was prepared by weighing the following composition in grams per litre (g/L): peptone, 5; yeast extract 3; malt extract 2, substrate 2 and $\mathrm{pH} 8$. The above medium composition were dissolved in $1000 \mathrm{ml}$ of distilled water after which $100 \mathrm{ml}$ of the medium was measured into a conical flask (250ml capacity each) heated on hot plate to homogenize and then sterilized in an autoclave at $121^{\circ} \mathrm{C}$ for 15 minutes after which they were removed and allowed to cool before inoculating.

\section{Extraction of Amylase and Protease Enzyme from $B$. subtilis}

After incubation, the production medium was centrifuged at $6000 \mathrm{rpm}$ for $30 \mathrm{~min}$ to separate the cells. The supernatant was collected as it contained the crude enzyme and stored at $4^{\circ} \mathrm{C}$ till further use.

\section{Extraction of amylase and protease enzyme from $A$. niger}

After the incubation period, extraction of the crude enzyme was done by centrifugation of the fermented media at 2000rpm (revolution per minute) for 5 minute. Supernatant 
collected were then filtered off using whatman's number 1 filter paper. The filtrate contained the crude amylase enzyme.

\section{Protease Enzyme Assay}

Casein solution of $2 \%(1 \mathrm{ml})$ was incubated with $1 \mathrm{ml}$ of enzyme solution and $1 \mathrm{ml}$ of sodium phosphate buffer $(\mathrm{pH} 7)$ for 20 minutes at $40^{\circ} \mathrm{C}$. The reaction was stopped using $10 \%$ Tricholoroacetic acid solution. After 20 minutes, the mixture was centrifuged at $10,000 \mathrm{rpm}$ for 5 minutes. After centrifugation the supernatant was developed with Bradford reagent and read at 580 $\mathrm{nM}$

\section{Amylase Enzyme Assay}

Amylase activity was assayed as described by Bertrand et al. (2004) by taking $1 \mathrm{ml}$ of the crude enzyme into each of the test tubes and $1 \mathrm{ml}$ of $1 \%$ soluble starch in sodium phosphate buffer having a $\mathrm{pH}$ of 6.4 .

\section{Effect of Temperature on the Production of Amylase}

The effect of temperature on amylase production was carried out using the following temperature values; $20^{\circ} \mathrm{C}$ $30^{\circ} \mathrm{C}, 40^{\circ} \mathrm{C}, 50^{\circ} \mathrm{C}, 60^{\circ} \mathrm{C}, 70^{\circ} \mathrm{C}$, and $80^{\circ} \mathrm{C}$ for both $\mathrm{B}$. subtilis and $\mathrm{A}$. niger after which an assay was carried out based on Dinitrosalicyclic acid method (DNSA), (Bertrand et al., 2004).

\section{Effect of pH on the Production of Amylase}

The effect of $\mathrm{pH}$ on the amylase production was carried out using the following $\mathrm{pH}$ values of $6,7,8,9$, and 10 for $B$. subtilis $\mathrm{pH}$ values and $\mathrm{pH}$ values $4,5,6,7$ and 8 was taken for A. niger while after which an assay was also carried out based on Dinitrosalicyclic acid method (DNSA) (Bertrand et al., 2004).

\section{Effect of temperature on protease production}

The effect of temperature on amylase production was carried out using the following temperature values; $20^{\circ} \mathrm{C}$, $30^{\circ} \mathrm{C}, 40^{\circ} \mathrm{C}, 50^{\circ} \mathrm{C}, 60^{\circ} \mathrm{C}, 70^{\circ} \mathrm{C}$ and $80^{\circ} \mathrm{C}$ for both $B$. subtilis and $A$. niger after which an assay was carried out (Bertrand $e t$ al., 2004).

\section{Effect of $\mathrm{pH}$ on protease production}

The effect of $\mathrm{pH}$ on the amylase production was carried out using the following $\mathrm{pH}$ values; $6,7,8,9$, and 10 for the $B$. subtilis while $\mathrm{pH}$ values of 4, 5, 6, 7 and 8 was used for the $A$. niger after which an assay was also carried out.

\section{Determination of reducing sugar}

The reducing sugars liberated were estimated by the 3,5 Dinitrosalicyclic acid (DNSA) method. The reaction mixed was incubated in a water bath at $40^{\circ} \mathrm{C}$ for 15 minutes and the reaction was terminated by adding $1 \mathrm{ml}$ of the prepared DNS reagent in the reaction tubes and then immersing the tubes in a boiling water bath $\left(100^{\circ} \mathrm{C}\right)$ for 5 minutes after which they were allowed to cool under running tap water. The absorbance of the resulting coloured solution was measured using a Jenway colorimeter at $540 \mathrm{~mm}$ against a blank prepared by substituting the hydrolyzed sample with $5 \mathrm{ml}$ of distilled water. The reducing sugar content was determined by mak- ing reference to the standard curve of known concentration for glucose (Bertrand et al., 2004).

\section{Result}

\section{Effect of pH on the activity of amylase enzyme produced by $B$. subtilis}

Figure 1 shows the effect of $\mathrm{pH}$ on the activity of enzyme produced by $B$. subtilis. The optimum $\mathrm{pH}$ for the activity of $B$. subtilis was recorded at $\mathrm{pH} 9$ in this study with a concentration of $1.2 \mathrm{mg} / \mathrm{ml} / \mathrm{sec}$.

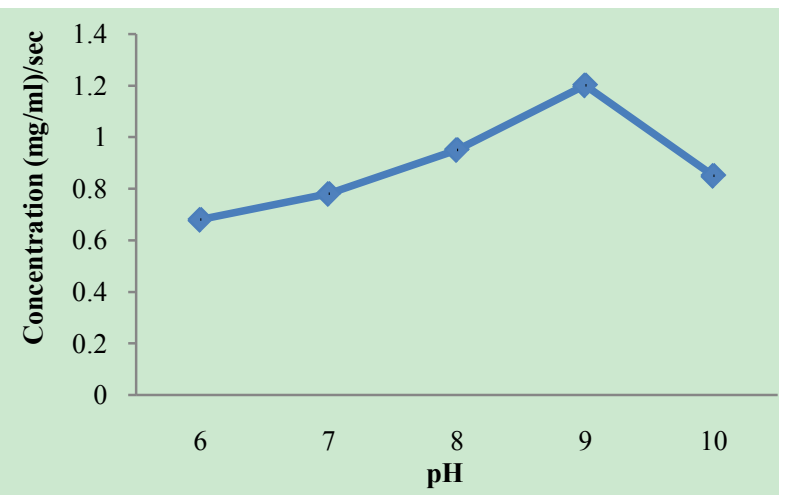

Figure 1. Effect of $\mathrm{pH}$ on amylase enzyme produced by B.subtilis

\section{Effect of pH on the activity of amylase enzyme produced} by $A$. niger

Figure 2 shows the effect of $\mathrm{pH}$ on the activity of enzyme produced by $A$. niger. The optimum $\mathrm{pH}$ for this study was recorded at $\mathrm{pH} 5$ with a concentration of $0.87 \mathrm{mg} / \mathrm{ml}$.

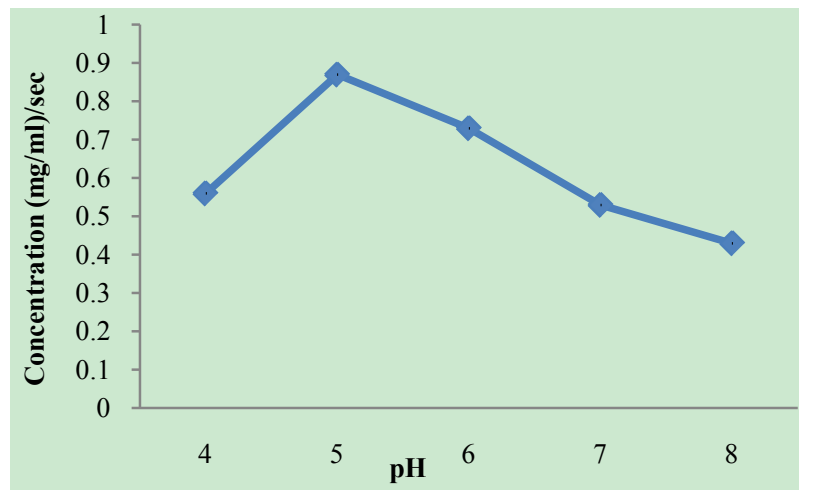

Figure 2. Effect of $\mathrm{pH}$ on amylase enzyme produced by A.niger

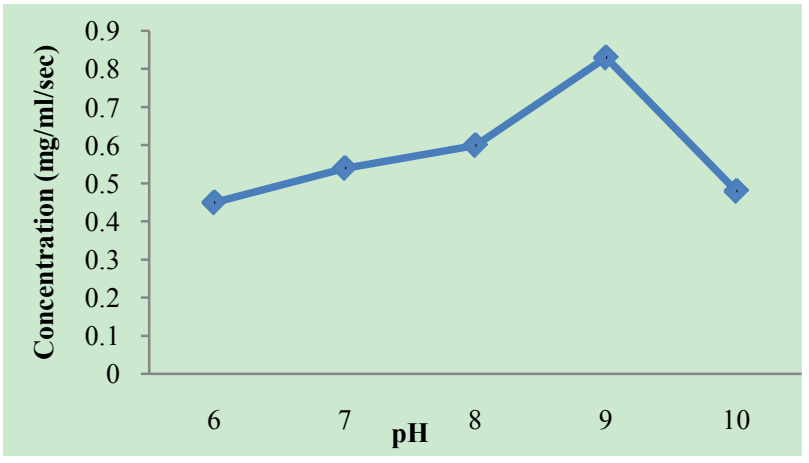

Figure 3. Effects of $\mathrm{pH}$ on protease activities produced by $B$. subtilis 


\section{Effect of pH on the activity of protease enzyme produced by $B$. subtilis}

Figure 3 shows the effect of $\mathrm{pH}$ on the activity of protease enzyme produced by Bacillus subtilis. The optimum $\mathrm{pH}$ was recorded $\mathrm{pH} 9$ with a concentration of $0.83 \mathrm{mg} / \mathrm{ml} / \mathrm{sec}$.

\section{Effect of $\mathrm{pH}$ on the activity of protease enzyme produced by $A$.niger.}

Figure 4 shows the effect of $\mathrm{pH}$ on the activity of protease enzyme produced by Aspergillus niger. The optimum $\mathrm{pH}$ was recorded at $\mathrm{pH} 6$ with a concentration of $0.74 \mathrm{mg} / \mathrm{ml} / \mathrm{sec}$.

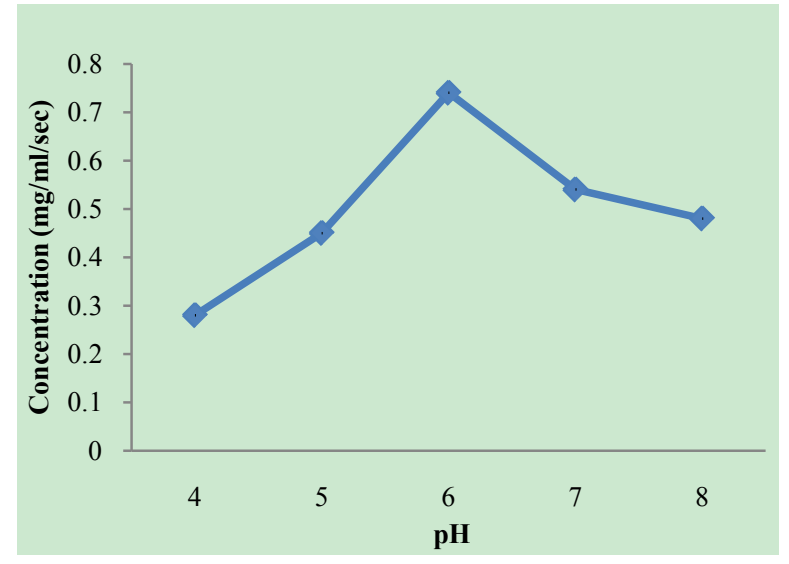

Figure 4. Effect of $\mathrm{pH}$ on protease activities produced by A. niger

Effect of temperature on the activity of amylase enzyme produced by $B$. subtilis and $A$. niger

Figure 5 shows the effect of temperature on the activity of enzyme produced by $B$. subtilis and $A$. niger. The optimum temperature for the activity of $B$. subtilis was recorded at $50^{\circ} \mathrm{C}$ with a concentration of $1.1 \mathrm{mg} / \mathrm{ml} / \mathrm{sec}$.

The optimum temperature for enzyme activity was recorded at $30^{\circ} \mathrm{C}$ with a concentration of $0.87 \mathrm{mg} / \mathrm{ml} / \mathrm{sec}$ for $A$. niger.

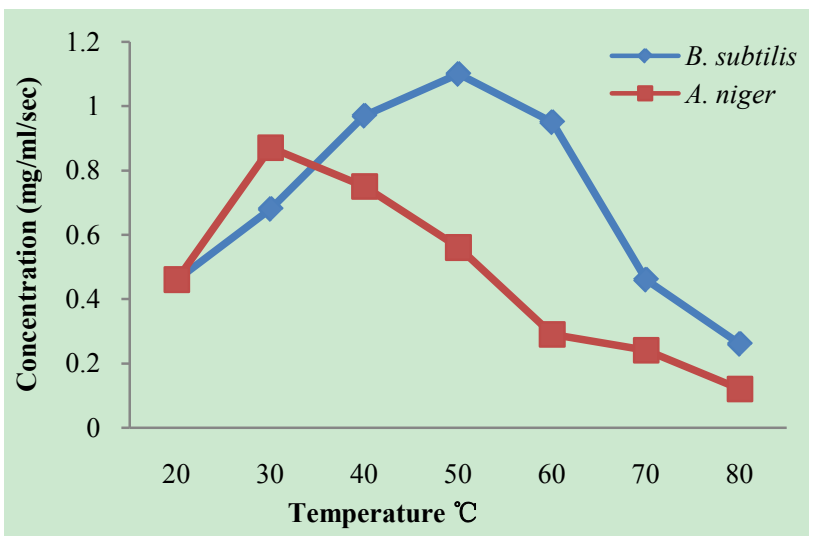

Figure 5. Effect of temperature on amylase enzyme produced by $B$. subtilis and A. niger

\section{Effect of temperature on the activity of protease enzyme produced by $B$. subtilis and $A$.niger}

Figure 6 shows the effect of temperature on the activity of protease enzyme produced by $B$. subtilis and $A$. niger. The optimum temperature for enzyme activity was recorded at $50^{\circ} \mathrm{C}$ with a concentration of $0.80 \mathrm{mg} / \mathrm{ml} / \mathrm{sec}$.
For A. niger, optimum temperature for enzyme activity was recorded at $40^{\circ} \mathrm{C}$ with a concentration of $0.77 \mathrm{mg} / \mathrm{ml} / \mathrm{sec}$.

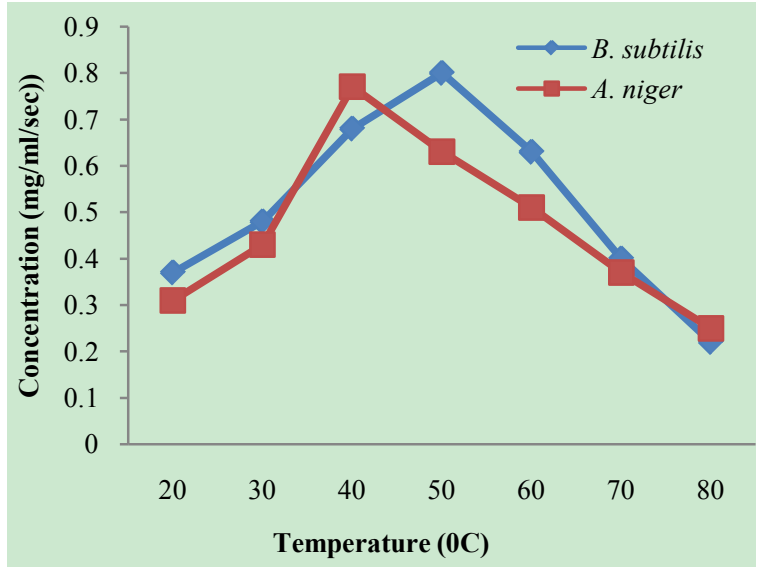

Figure 6. Effect of temperature on protease enzyme B.subtilis and A. niger

\section{Discussion}

The production of amylase and protease enzymes by $B$. subtilis and $A$. niger using $P$. biglobossa as substrate in solid state fermentation was carried out in shake flask. Bacillus subtilis showed highest protease enzyme activity at temperature range from $40-60^{\circ} \mathrm{C}$. The optimum temperature was attained at $50^{\circ} \mathrm{C}$ with a concentration of $0.80 \mathrm{mg} / \mathrm{ml} / \mathrm{sec}$.

Protease enzyme activity decreases from $60^{\circ} \mathrm{C}$, this may be due to the fact that at higher temperature enzymes are denatured. Gitishree et al. (2010) reported maximum protease production at $40^{\circ} \mathrm{C}$. The effect of temperature on the activity of protease enzyme produced by $A$. niger revealed that there was a sudden increase in protease production from $30-40^{\circ} \mathrm{C}$ with a concentration of $0.43 \mathrm{mg} / \mathrm{ml} / \mathrm{sec}$ and $0.63 \mathrm{mg} / \mathrm{ml} / \mathrm{sec}$. However there was sudden decrease in the activity of enzyme produced by $A$. niger when the temperature was increased above $50^{\circ} \mathrm{C}$. This result agrees with Kalpana et al. (2008), that protease production decrease with increasing temperature from $35-45^{\circ} \mathrm{C}$ and that protease production ceases at higher temperature. Oyeleke et al. (2010), reported maximum protease yield for $A$. flavus and $A$. fumigatus at $30^{\circ} \mathrm{C}$.

The optimum $\mathrm{pH}$ for the enzyme produced by $A$. niger for this study was recorded at $\mathrm{pH} 6$ with $\mathrm{pH}$ range of 7-8 also supporting enzyme activity. Kalpana et al. (2008) reported maximum protease production at for $A$. niger at $\mathrm{pH}$ 7-9 and recorded maximum protease production at $\mathrm{pH}$ 8.5. In a similar findings, Oyeleke et al. (2010) reported the optimum $\mathrm{pH}$ for the activity of protease produced by A. flavus and $A$. fumigatus as $\mathrm{pH} 8$ and $\mathrm{pH} 5$ respectively. The optimum $\mathrm{pH}$ for protease production by Bacillus subtilis in this study was recorded at $\mathrm{pH} 9$ with a concentration of $0.83 \mathrm{mg} / \mathrm{ml} / \mathrm{sec}$. In a similar findings (Gitishree et al., 2010), reported maximum protease production at $\mathrm{pH} 8$.

Temperature and $\mathrm{pH}$ are the most important factor affecting enzyme activity. The effect of temperature and $\mathrm{pH}$ was studied for the production of amylase enzyme by $A$. 
niger and B. subtilis. A. niger had a optimum temperature at $30^{\circ} \mathrm{C}$ with a concentration of $0.87 \mathrm{mg} / \mathrm{ml} / \mathrm{sec}$. Temperature of $40^{\circ} \mathrm{C}$ also supported the enzyme but dropped as the temperature increases. $B$. subtilis had enzyme activity at various temperature range from $30-60^{\circ} \mathrm{C}$ with optimum temperature recorded at $50^{\circ} \mathrm{C}$ with a concentration of $1.1 \mathrm{mg} / \mathrm{ml} / \mathrm{se}$. Further increase in temperature was followed by decrease in enzyme activity. This s similar to the work of Oyeleke and Oduwole, (2009); Daniel et al. (2010); Oyeleke et al. (2010), that during isomerisation, temperature is preferably maintained within the range $20-90^{\circ} \mathrm{C}$ and the best activity is obtained with $50-70^{\circ} \mathrm{C}$.

Maximum amylase yield was obtained at $\mathrm{pH} 5$ for $A$. niger, with $\mathrm{pH}$ 4-7 also supporting amylase production. This result suggests the slightly acid nature of the amylase produced. Maximum amylase yield for $B$. subtilis was recorded at $\mathrm{pH} 9$, although, $\mathrm{pH}$ 7-10 supported amylase production. This result suggests that maximum amylase production was obtained at alkaline $\mathrm{pH}$. The vast activity of amylase enzyme at various $\mathrm{pH}$ suggest the wide application nature of the amylase enzyme identified. (Oyeleke and Oduwole, 2009), reported the similar findings between $\mathrm{pH}$ range of 6-8. This result suggests that the B. subtilis used for this work functions best at alkaline $\mathrm{pH}$.

In this study, Bacillus subtilis and Aspergilus niger have proven to be useable in the conversion of agricultural wastes into useful product (enzymes). Therefore, more agricultural waste should be screened for their ability to be utilized as possible substrate for the production of enzymes.

\section{REFERENCES}

[1] Bertrand, T.F., Frederic, T. and Robert, N. (2004). Production and Partial Characterization of a thermostable amylase from
Ascomycetes yeast strain isolated from starchy soil. McGraw-Hill Inc., New York. pp. 53-55

[2] Burhan, A., Nisa, U., Gokhan, C., Ashabil, A. and Osmair, G. (2003). Enzymatic Properties of a novel thermostable thermophilic alkaline and chelator resistant amylase from an alkaphilic Bacillus sp Isolate ANT-6. Process Biochemistry. (38): 1397-1403

[3] Enzyme Technical Association (2001). Enzymes; A primer on use and Benefits today and tomorrow. Washington, DC 200036 pp. $1-32$

[4] Daniel R.M., Peterson M.E., Danson M.J. (2010). The molecular basis for the effect of temperature on enzyme activity. Biochemistry Journal 425(2): 353-360

[5] Gitishree, D. and Prasad, M.P. (2010). Isolation, purification and mass production of protease enzyme from Bacillus subtilis. International Journal of Microbiology 1(2):026-031

[6] Kalpana, D.M., Gnanaprabhal, G.R., Palaniswamy, M. (2008). Purification and characterization of alkaline protease enzyme from native isolate Aspergillus niger and its compatibility with commercial detergents. Indian Journal of Science and Technology (7) 1-7

[7] Kurebgaseka, N. (2005). Report and research into Africa smootie market and The Potential for Baobob Fruit Pulp as an Ingredient in Smoothies. PhytoTrade Africa (1): 1-35

[8] Mitra P., Chakraverty, R. and Chandra, A. L. (1994). Production of proteolytic enzyme in solid state fermentation system. Brazilian Journal of Science Research (55):439-442

[9] Oyeleke, S.B and Oduwole, A.A. (2009).Production of amylase by bacteria isolated from a cassava dumpsite in minna, Nigerstate, Nigeria. African Journal of Microbiology Research volume 3(4): 143-146

[10] Oyeleke, S.B., Egwin E.C. and Auta S.H. (2010). Screening of Aspergillus flavus and Aspergillus fumigates strains for extracellular protease enzyme production. Journal of Microbiology and Antimicrobials Volume 2(6): 2141-2307 